\title{
Unidade, coerção e desvio na literatura patrística pós-nicena: a ontologia moral e a condição judaica no pensamento de Agostinho de Hipona
}

\author{
Renata Rozental Sancovsky \\ Universidade Federal Rural do Rio de Janeiro \\ Rio de Janeiro, RJ, Brasil \\ rrsancov@gmail.com
}

\section{RESUMO}

Este artigo analisa as práticas discursivas referentes às relaçóes entre mito e filosofia no pensamento agostiniano sobre a condição judaica nos primeiros séculos medievais. Serão discutidos semânticas e alcances do pensamento mítico sobre o chamado "comportamento filosófico" pós-niceno, demonstrando fortes aproximaçôes entre os dois campos da existência humana. A partir das ressignificaçôes operadas nas práticas literárias dos séculos IV e V, os escritos agostinianos revelam que o mito e a filosofia passam a compor, conjuntamente, o universo identitário construído pela patrística clássica, ora identificado a partir de concepçóes em torno da divindade, da história e do ser.

Palavras-chave: patrística pós-nicena; Igreja Católica; neoplatonismo; judaísmo; heresia.

\begin{abstract}
This paper analyzes the discursive procedures concerning the relationship between myth and philosophy in Augustinian thought on the Judaic condition in Early Middle Ages. Some semantic issues and the reach of mythical thought on the so-called post-nicene "philosophical behavior" will be debated, showing the considerable proximities between the two areas of human existence. Throughout the new meanings of literary practices established during the fourth and the fifth centuries, the Augustinian writings reveal that from then on myth and philosophy make up, together, the identitary universe built by classical patristics, which can be defined through concepts regarding divinity, History or the being. Keywords: post-nicene patristics; Catholic Church; Neoplatonism; Judaism; heresy.
\end{abstract}


A narrativa agostiniana sobre os judeus sempre representou importante conteúdo de debates acadêmicos. Há que se considerar, entretanto, que grande parte dos estudiosos, ao depurarem as colocaçóes do bispo de Hipona, tende a situá-las entre as fronteiras de uma tolerância equilibrada e o desejo episcopal de localizar funcional e socialmente os judeus no âmago do que, anacronicamente, identificam como "Cristandade".

A tese do "equilíbrio agostiniano", desenvolvida, a exemplo, por historiadores como Keneth Stow e Jeremy Cohen ${ }^{2}$, apresenta-nos um Agostinho piedoso e de certa forma tolerante, fiel ao helenismo judaico-cristão disposto no longo epistolário paulino.

Apoiando-se exclusivamente em alguns trechos de De Civitate Dei, Keneth Stow revela-nos um Agostinho preocupado com os rumos universalistas de sua Igreja, cujo discurso destoaria das tendências destrutivas do antijudaísmo dos primeiros séculos da Idade Média ${ }^{3}$. As heranças ideológicas do cristianismo de Paulo justificariam, para Stow, o caráter moderadamente tolerante da narrativa agostiniana preconizando, antes de tudo, o ideal da preservaçáo judaica em sociedade.

Assim, ao apresentar sua leitura sobre o pensamento de Agostinho, comete alguns equívocos e simplificaçóes interpretativas: o autor acredita que o trabalho agostiniano sobre os judeus pode ser tipificado através dos ensinamentos referentes à tese do "testemunho judaico". Adversus iudaeos, texto tardiamente produzido pelo bispo de Hipona em 429, é resumido pelo historiador como uma proposta exclusiva de difusão da "permanência judaica condenada", tida apenas como testemunho da verdade cristá. $\mathrm{O}$ autor insiste na hipótese de que, em momento algum de sua produçáo polêmica, Agostinho intencionara isolar os judeus da sociedade, ou mesmo rechaçá-los à condição de criminalidade através dos recursos da violência ${ }^{4}$.

Para Stow, as relaçôes religiosas entre cristãos e judeus anunciadas pelo bispo seriam balizadas pelo discurso da não intransigência sobre as concepçôes. Segundo a tese do "equilíbrio", o discurso eclesiástico da intolerância não se aplicaria ao pensamento de Agostinho. Mesmo condenando o judaísmo à categoria de erro e pecado, os direitos judaicos quanto à continuidade existencial e à preservação moral estariam garantidos. Para Agostinho, segundo os estudiosos do equilíbrio, o judaísmo não deveria desaparecer e seus seguidores não deveriam ser submetidos a quaisquer formas de coerção religiosa. Apenas sobreviveriam porque, uma vez preservados, serviriam funcional e exemplarmente como espelhamento antagônico à comunidade cristã.

Provavelmente, o cerne da reflexão historiográfica "do equilíbrio" foi encontrado na formulação de Agostinho, em que decreta um penoso destino histórico ao povo judeu: a condição errante, a submissão à Igreja como instrumentos (e não alvos) humanos da atividade evangelizadora, e a preservação do judaísmo.

(...) Sobre sua dispersão pela superfície, onde quer que se encontre a Igreja, pode-se ler a profecia, em um dos salmos expressa nos seguintes termos: Meu Deus me prevenirá com sua misericórdia. Meu Deus me há de mostrá-la em meus inimigos, dizendo-me: Não acabes com eles, para não esquecerem tua lei. Dispersa-os com teu poder. Deus, por conseguinte, mostrou à Igreja, em seus inimigos, os judeus, a graça de sua misericórdia, porque, como diz o Apóstolo, seu pecado oferece às nações a oportunidade necessária para se salvarem. E não

${ }^{1}$ STOW, Keneth R. The augustinian equilibrium. In: Alienated minority: the Jews of medieval latin Europe. Harvard University Press, 1992. p. 17-18.

${ }^{2}$ COHEN, Jeremy. Living letters of the law: ideas of the Jew in medieval Christianity. S. Mark Taper Foundation Imprint in Jewish Studies; University of California Press, 1999. Ver também STOW, Keneth R. The augustinian equilibrium, op. cit.

${ }^{3}$ STOW, K. The doctrine of Jewish witness. In:

${ }^{4}$ Ibidem, p. 18. 
os matou, que dizer, neles não destruiu o Judaísmo, embora vencidos e subjugados pelos romanos, de medo que, esquecidos da lei de Deus, não pudessem oferecer-nos testemunho do que tratamos 5 .

Nesta formulação, talvez uma das mais citadas por estudiosos de Agostinho, o bispo define que os inimigos da Igreja não deveriam ser extirpados, mas conservados em sua inferioridade e desprezo, exatamente porque utilizados como canais de memória da lei cristã. Sua marginalização e seus pecados deveriam ser relembrados como estímulos à salvação "de todas as gentes". A suposta benevolência do discurso episcopal finda então por tipificar os judeus como aqueles efetivamente "inimigos", a quem a Igreja estenderia sua piedade ao mostrar-lhes a lei. Dispersos e pecadores, serviriam, nas localidades onde a Igreja alcançasse, como testemunhos vivos das "profecias" alegoricamente identificadas nas Escrituras.

A complexidade filosófica do pensamento de Agostinho nos encaminha a interpretaçóes mais audaciosas sobre seus textos. Para tal, é necessário que direcionemos nosso trabalho para o campo da desconstrução e análise dos discursos de elite que, sob o respaldo religioso, formulam projetos de exclusão e dominação, baseados em atributos como o mito, o estigma ${ }^{6}$, o evitamento simbólico e físico ${ }^{7}$.

Afirmemos, inicialmente, que os episódios de conversão coletiva, ocorridos com a comunidade judaica balear de Menorca (Mahón), em 417 d.C., e deflagrados pelos trabalhos de um dos maiores discípulos de Agostinho - Paulo Orósio —, seriam apenas a primeira grande inflexão prática de seu pensamento a respeito dos judeus, e de suas necessárias conversóes no Mediterrâneo Ocidental. Paulo Orósio foi o responsável pela chegada das supostas relíquias do martírio de Estevão à Península Ibérica, fator que, a posteriori, teria impulsionado a conversão maciça de toda a comunidade judaica da referida diocese, com anuência do bispo Severo.

Argumenta o hispanista Raul González-Salinero que a ausência de insultos destrutivos e o uso de um vocabulário mais "cuidadoso" para referir-se aos judeus seriam fatores de fato diferenciais no discurso cristológico de Agostinho ${ }^{8}$, quando comparado às demais produçóes da Patrística clássica nicena. Entretanto, consideramos que tais indícios não seriam indicativos de aceitação ou inoperância benevolente na ideologia agostiniana. Uma leitura desatenta dos escritos do bispo de Hipona nos induziria à simples constataçáo de que todas as suas críticas contra os judeus permaneceriam apenas no plano teológico e da contra-argumentação messiânica, sem sugerir um dimensionamento prático. Logo, a aparente passividade de seu discurso poderia encaminhar o historiador a um simplismo analítico de mera discordância religiosa, exclusivamente antijudaica.

Com tendência analítica correlata, Saul Kirschbaum, em interessante artigo, desconstrói o discurso agostiniano apresentado no tratado Confessiones. Identifica uma hermenêutica agostiniana cujo escopo seria propor e afirmar a inversão da tradição talmúdica, e sua consequente deslegitimação exegética.

\footnotetext{
${ }^{5}$ AGOSTINHO DE HIPONA. A Cidade de Deus contra os pagãos. 3. ed. Petrópolis: Vozes; São Paulo: Federação Agostiniana Brasileira, 1990. v. 2, Livro 18, Capítulo XLVI, p. 365-366. (Coleção Pensamento Humano); AUGUSTINI HIPPONENSIS. De Civitate Dei adversus paganus. In: PATROLOGIA LATINA database. Paris: Garnier, 1844/1864. Patrologia de Jacques-Paul Migne. v. 42, Liber XVIII, Caput XLVI. (Série Latina).

${ }^{6}$ Cf. GOFFMAN, Erving. Estigma. Notas sobre a manipulação da identidade deteriorada. Rio de Janeiro: Zahar, 1990. p. $12-13$.

${ }^{7}$ CARNEIRO, M. L. T. O discurso das elites: versôes sobre os excluídos. Programa de Pós-Graduação em História Social da USP, 2003. Mimeografado.

${ }^{8}$ Considera-se então que o pensamento agostiniano “(...) contribuiría de forma extraordinaria a una visión de la realidad del judaísmo que iba más allá del simple insulto y que, por ello, daría lugar a una posición antijudía cuyas consecuencias determinaron una mayor degradación del judio como elemento extraño, pero al mismo tiempo servil, dentro de la sociedad cristiana. En este sentido, la influencia de Agustín a través de su teoría del pueblo testigo sería decisiva primero en otros escritores cristianos y después en el fundamento ideológico del antijudaísmo medieval”. GONZÁLEZ SALINERO, Raúl. El antijudaísmo cristiano occidental (siglos $I V y V$ ). Prólogo de Gonzalo Puente Ojea. Madri: Editorial Trotta, 2000. p. 204-205.
} 
Concordamos com Kirschbaum quando localiza um Agostinho envolto em combates ideológicos contra o proselitismo judaico e o paganismo. Entretanto, ainda que condizentes com nossa perspectiva de análise, as hipóteses de Kirschbaum ${ }^{9}$ não abordam os desdobramentos práticos da ideologia agostiniana, atendo-se exclusivamente ao estudo dos campos dos conflitos exegéticos entre Cristianismo e Judaísmo.

\section{Lógos et Verbum: ontologia moral neoplatônica e a assimetria do outro}

Com base nos componentes socráticos presentes no pensamento de Platão, é possível analisar alguns dos principais desdobramentos axiomáticos do platonismo sobre a teologia. O que para os gregos significaria dar razão a algo, explicando-o, através da lógica inovadora do lógos, o pensamento cristão faria por se reapropriar das fórmulas racionais, transformando-as em Verbum ${ }^{10}$, base inconteste da construção dogmática do cristianismo e evidência da revelação divina.

Sabe-se que a ontologia platônica está essencial e intrinsecamente associada ao conceito de lógos, elemento do ser que apresentaria uma conformidade unitária (sintética), coerente e existencial. Posto que perfeito, o lógos platônico configurar-se-ia, pois, como instância divina, raciocínio este de grande relevância para os argumentos filosóficos da Patrística clássica medieval.

O mundo sensível, em Platão, estaria longe de representar efetivamente o ser. Em antítese, o mundo inteligível explicaria e conteria, portanto, a pureza, a perfeição, e a eternidade condizentes com o ser - o lógos. Em A república, Platão elabora interessantes analogias explicativas da diferenciação entre o sensível e o inteligível. O primeiro seria apenas como a sombra projetada de um objeto qualquer. Entre a sombra e objeto que inspira a projeção, revelam-se diferenças cruciais e intransponíveis. As sombras seriam apenas "partículas da realidade" verificadas originalmente no mundo inteligível.

O mundo sensível, posto apenas como o universo das sombras, das conjecturas e das ilusôes do espírito, nada mais significaria para Platão do que o não ser, o ser em outro. Essa inautenticidade intrínseca ao universo sensível faria dele o cerne para a construção da falsidade, do mal e da inverdade.

O mundo legítimo só poderia ser alcançado na esfera do inteligível. A verdade e a moral representaram, nesse sentido, categorias apenas apreendidas de fato na legitimidade do ser que é, do ser autêntico e, portanto, divino. Da sombra à luz, transita-se do mundo sensível ao inteligível, e contemplam-se, neste momento, todas as instâncias idealmente necessárias para a formação da sociedade e da cidade ideais. No inteligível atinge-se o bem, o mundo das ideias, do conhecimento e, sobretudo, da razão.

Os axiomas platônicos supracitados encontraram terreno fértil para reinterpretação a partir das reflexôes do bispo hiponense. Podemos afirmar, inclusive, a existência de um neoplatonismo agostiniano, que trabalha de forma análoga, pela relação que estabelece entre o ser e o lógos. Este continua a ser adotado por Agostinho como critério ontológico indiscutível para o entendimento do ser e da existência no devir, autêntico e verdadeiro.

$\mathrm{Na}$ construção doutrinária dos alicerces políticos da ecclesia katoliké, a ontologia cristã pós-nicena apropria-se com grande habilidade axiológica do lógos de Platão, e o transforma em Verbum. A lei da casa (oikonomia) e a lei da congregação de fiéis (ecclesia) dependem de sua preservação pela hierarquia, doutrina e instituição eclesiásticas. Entre os séculos IV e V, ao definir concepçóes centrais da identidade moral e espiritual do cristianismo de aportes paulinos, o lógos, assim como o Verbum, seriam incorruptíveis, necessários e infalíveis. Afastados do mal e da temível ameaça da descrença, quando adaptados pela lógica agostiniana, adquirem o sentido universal de um oikos cristão. Deveriam ser entendidos e

\footnotetext{
${ }^{9}$ KIRSCHBAUM, Saul. Santo Agostinho: Confissões. Vértices, São Paulo, n. 3, p. 160-161, 2003.

${ }_{10}$ Termo análogo a Dei na literatura agostiniana, neste artigo apresentamos o termo latino Verbum com sua inicial maiúscula.
} 
difundidos antes como convicçôes do ser moral, extensíveis a todas as "gentes", e não somente àqueles que já haveriam abraçado de vera religione ${ }^{11}$. Seriam também veículos religiosos únicos para o verdadeiro conhecimento de si do homem ${ }^{12}$.

O filósofo Ernst Cassirer chega a considerar, inclusive, que a "unidade e homogeneidade" reconhecida nos propósitos da filosofia teológica medieval direcionaram profundamente o processo de construção das chamadas "teorias de Estado". Ao legitimar poderes monárquicos e eclesiásticos a partir do século V, Agostinho, como tantos outros padres da Igreja, apropriava-se com destreza do pensamento grego, neoplatônico em sua essência, entendendo que todos os processos racionais que levavam ao conhecimento seriam sobretudo atos divinos, ou, antes, vetores do divino ${ }^{13}$.

Em Confessiones, Agostinho reafirma, finalmente, a similitude entre palavra e sabedoria. Quando “o Verbo se faz homem”, o lógos, a racionalidade necessária a uma existência inteligível, torna-se agora instância divina, verdadeira, apresentada na forma humana a todos os entes, através de Cristo. A "verdade eterna" do Verbum não seria apenas uma constatação teológica, mas um axioma humano, uma diretriz de toda a existência. A humanização do Verbum, revelada em Cristo, deveria ser um princípio ético universalmente aceito. Objetivamente aplicado, teria de ser compreendido como central ao pensamento, causa e efeito do ato de pertencer à oikoumene, único caminho possível para a vida humana $\mathrm{e}$ sua salvação.

(...) Ele chamava-me e dizia: "Sou o caminho, a Verdade e a Vida." [João, 14,6]. Eu também devia crer que o Alimento que era incapaz de tomar se uniu à carne, pois o "Verbo se fez homem" [João, 1,14], para que a vossa Sabedoria, pela qual criastes tudo, se tornasse o leite da nossa infância. (...) Com efeito, o vosso Verbo, Verdade eterna, exaltado sobre as criaturas mais sublimes, ergue até si os que se lhe sujeitam ${ }^{14}$.

Neste ponto, Agostinho é tácito ao defender que o ser só existiria caso contivesse a essência e a palavra de Deus. Em Confessiones, reflete sobre o ser unido ao Verbum. O ser universalmente pensado e o divino em Cristo transformam-se em substâncias inseparáveis, percebendo que "nada do que existe" poderia existir ontologicamente sem a onipotência do Verbum:

(...) Será, talvez, pelo fato de nada do que existe poder existir sem Vós, que todas as coisas Vos contêm? (...) Por conseguinte, não existiria, meu Deus, de modo nenhum existiria, se não estivésseis em mim. Ou antes, existiria eu se não estivesse em Vós, "de quem, por quem e em quem todas as coisas subsistem? Assim é, Senhor, assim é"15.

Portanto, a infinita luta maniqueísta do bem contra o mal, para Agostinho, resumir-se-ia à luta do lógos/Verbum (fórmula racional para a compreensão do ser divino) contra os seres que não o seriam verdadeiramente, posto que falsos, ilusórios e nocivos. Em seu diálogo imaginário com a divindade, a oposição entre o sensível e o inteligível está cabalmente presente nas palavras do bispo. Em interessante trecho de Confessiones, opóe o ser uno e bom (cristáo) às criaturas, todas necessariamente envoltas em erros e ilusões: “(...) Eu pecava, porque em vez de procurar em Deus os prazeres, as grandezas e as verda-

\footnotetext{
${ }^{11}$ AUGUSTINI HIPPONENSIS. De vera religione. In: PATROLOGIA LATINA database, op. cit. v. 42. AGOSTINHO DE HIPONA. A verdadeira religião. 3. ed. Petrópolis: Vozes; São Paulo: Federação Agostiniana Brasileira, 1990. (Coleção Pensamento Humano).

${ }^{12}$ CANDAU, J. M.; GASCÓ, F.; RAMÍREZ de VERGER, A. (Ed.). La conversión de Roma. Cristianismo y paganismo. Madri: Ediciones Clásicas, 2000. p. 100.

${ }^{13}$ CASSIRER, Ernst. O mito do Estado. São Paulo: Códex, 2003. p. 110-112.

${ }^{14}$ AUGUSTINI HIPPONENSIS. Confessiones, op. cit. v. 42, Liber VII, Caput 18.

${ }^{15}$ Ibidem, Liber I, Caput 2.
} 
des, procurava-os nas suas criaturas: em mim e nos outros. Por isso, precipitava-me na dor, na confusão e no erro. Não queria ser enganado" 16 .

Como vemos, o realismo ideal e a unidade do ser, pressupostos sabidamente platônicos, também se configuram molas mestras do pensamento de nosso autor. Sua excessiva preocupaçáo com a moral e o reconhecimento de que a verdade só poderia ser encontrada no Verbum levam-no a reflexóes de ordem social bastante significativas. A analogia filosófica — verdade e Verbum — denota de que forma o bispo de Hipona entendia a presença social de componentes não cristãos em meio à cristandade, ou, ainda, de cristãos cujos poderes inventivos seriam considerados heréticos.

A pureza dos entes morais, enfim, só seria contemplada caso o Verbum fosse integralmente reconhecido pelos seres. Apropriando-se do imaginário paulino sobre os erros judaicos na recusa da lei, é na Epístola aos romanos $(10,14)$ que o hiponense respalda-se para atestar que a fé em Cristo seria o único canal viável da inteligibilidade da razão do mundo. Sem esta, permaneceria o ser na esfera do sensível e do transitório ${ }^{17}$.

O realismo construído outrora por Platão foi, portanto, desdobrado por Agostinho em Confessiones e em De Civitate Dei adversus paganus. A cidade ideal (aprioristicamente idealizada por Platáo em A república), fora imaginada como um espaço onde a palavra prevaleceria sobre toda e qualquer forma inautêntica de ser. Nessa cidade, Deus (Cristo) suplantaria o mal, socialmente concretizado na presença de forças estranhas ou contrárias à Cristandade.

Neste sentido, o autor cria o arquétipo do antagonismo entre Verbum e haeresis, quando confessa, em gesto de humildade intelectual, o tempo levado para aprender sobre as diferenças entre a "verdade católica" e o erro dos hereges. Agostinho opóe sistematicamente aquilo que "contém a sã doutrina" alavancada pelos "fortes" aos sentimentos reprováveis dos heréticos, como Fotino, que buscavam, por suas inerentes "fraquezas", questionar a absoluta forma humana do Verbum como divindade, defendida pela teologia católica: "Foi necessário haver hereges para que os fortes se manifestassem entre os fracos [1 Coríntios, 11,19]"18.

É necessário considerar que Fotino, bispo da diocese de Sírmio no século IV, foi considerado herético pela doutrina católica por fazer objeções à união do Verbum com a matéria, fusão esta defendida por Agostinho. Fotino, como da mesma forma pregou o bispo Ário (considerado herético pelo Concílio de Niceia de 325 d.C.), atribuía a Jesus uma condição semidivina, antes Filho de Deus do que propriamente Deus, pensamentos incongruentes às tendências homogeneizadoras e dicotômicas da filosofia dos Padres da Igreja.

Como se pode constatar, em meio às querelas agostinianas contra os heréticos, as preocupaçôes morais localizadas em Platão são transpostas aos planos do hiponense, à medida que o uno estivesse consubstanciado na Igreja, ou propriamente na moral institucional eclesiástica.

O uso simbólico do tempo e as alegorias interpretativas das sagradas escrituras são importantes artifícios hermenêuticos utilizados não somente por Agostinho, mas por toda a Patrística clássica pós-nicena. Nas disputas dicotômicas do bem contra o mal, o apego ao simbolismo acelerava a construçáo dos antagonismos morais que legitimavam o projeto incorporado pela Igreja a partir do século $\mathrm{V}$.

Em De Civitate Dei, redigida entre 413 e 424, veríamos o esboço do ideal agostiniano de humanidade, sociedade e religiáo. Há que se considerar, contudo, que o realismo agostiniano estimulou não apenas a elaboração de um locus divinizado, repleto de dimensóes utópicas e contemplativas, mas, fundamentalmente, remete o autor à construção de um arquétipo político, por meio do qual propóe critérios de divisão e organização sociais, considerados ideais para seu tempo.

\footnotetext{
${ }^{16}$ Ibidem, Liber I, Caput 20.

${ }^{17}$ Ibidem, Liber I, Caput 1.

${ }^{18}$ Ibidem, Liber VII, Caput 19.
} 
$\mathrm{Na}$ verdade, mais imediatista e menos passional, Agostinho, em diversas de suas epístolas - algumas redigidas inclusive em meio à iminente derrocada do Império Romano - , assume importante papel na luta intelectual e prática, não só contra tendências heréticas veiculadas no norte da África, como o "donatismo", mas também, na luta contra o judaísmo. Consubstancia tal reconhecimento, defendendo a instauração de instrumentos de perseguição e de políticas governamentais como meios de controle e opressão sociais. Vendo a perseguição como algo necessário para a difusão do "bem", nosso autor escapa ao universo de estigmatização ideológica ou simbólica ao qual buscou manter-se fiel, e passa a adotar categorias de exclusão que poderíamos denominar como físicas e sociais ${ }^{19}$.

A premência de políticas de combate às escolhas divergentes aos princípios do caminho denota a unidade da fé como eixo discursivo da lei, da hierarquia, da ecclesia. Todo e qualquer processo persecutório que viesse a ser aplicado não o seria por maldade ou iniquidade do corpo eclesiástico, mas por profundo e verdadeiro sentimento de piedade com relação ao ser perseguido. Com tal intuito, Agostinho chega, inclusive, a inverter a ordem hierárquica dos protagonistas. Ao externar, na Epístola XCIII a Vicente Rogatista (408 d.C.), suas inquietações sobre as relações de poder entre Igreja e Sinagoga, afirma ser a primeira aquela que padece perseguida pelo "Israel carnal", a saber, os judeus.

Assim, por obra da excessiva soberba e impiedade dos entes "carnais", a Igreja haveria passado por longos processos persecutórios. Por essa razão, escreve Agostinho, toda ação cometida pela "autêntica e legítima mãe" em seu tempo, por mais que pudesse parecer "áspera ou amarga", não o seria no sentido de "pagar o mal pelo mal", mas sim "proporcionar o bem pela disciplina", expulsando o mal intrínseco à iniquidade dos humanos. Agostinho relaciona os atos "ásperos e amargos" da Igreja a um gesto de amor saudável e piedoso pelas criaturas carnais, e jamais como um conjunto desordenado de atitudes movidas por "ódio daninho". Em seguida, defende a necessidade do uso da perseguiçáo como prova de amor a Deus e ao homem. No caso das perseguiçóes promovidas pela Igreja, afirma o bispo de Hipona haver exclusivamente objetivos morais e éticos, condizentes com o Verbum, ou seja, com a representação divina na cidade terrena. Ao contrário daqueles que perseguiam por crueldade e injustiça, a Igreja de Agostinho, ao perseguir, estaria beneficiando a disciplina a serviço da caridade, promovendo o bem à humanidade ${ }^{20}$.

Nota-se que a identidade carnal atribuída por Agostinho aos judeus retira-lhes de imediato o direito de prosseguirem sob condição identitária e hereditária de um Israel, revertido agora em metáfora da correta escolha de fé. O imaginário agostiniano constrói importantes arquétipos de caráter mitológico, em que judeus representariam apenas a versão carnal do verdadeiro Israel. Desvinculada da identidade judaica, a versão espiritual desse Israel, mais verdadeira e mais próxima dos desejos divinos, seria assumida pelos cristãos, ou, mais propriamente, pela Igreja.

Em Adversus Iudaeos, Agostinho insiste na diferenciação entre Israel carnal e Israel espiritual. Conforme demonstrou o historiador Daniel Boyarin ${ }^{21}$, o platonismo agostiniano permitiu uma elaboração intelectual onde o Israel carnal, análogo ao ser sensível de Platão, adquire feiçóes negativas, mundanas e pecaminosas. O historiador localiza diferenciações entre cristãos e judeus feitas por Agostinho, principalmente no tocante ao corpo e sua simbologia religiosa ${ }^{22}$.

Os judeus, renegando e conspirando contra Cristo, teriam perdido uma posiçáo existencial privilegiada “(...) Ide agora, ó Israelitas conforme a carne, não conforme o espírito, ide agora, e até aí con-

\footnotetext{
${ }^{19}$ CHARTIER, R. Au bord de la falaise. L'Histoire entre certitudes et inquiétudes. Albin Michel, 1990. p. 89-90.

${ }^{20}$ AGOSTINHO DE HIPONA. Cartas. In: OBRAS de San Agustín. Edición bilingüe. Madri: BAC, 1951. Carta 93, “A Vicente Rogatista (año 408)”. Capítulo II, 6,8. AUGUSTINI HIPPONENSIS. EPISTOLA XCIII. In: PATROLOGIA LATINA database, op. cit. v. 33, Caput II, 6; Caput II, 8.

${ }^{21}$ Cf. BOYARIN, Daniel. Israel carnal: lendo o sexo na cultura talmúdica. Rio de Janeiro: Imago, 1994. p. 13.

${ }^{22}$ Ibidem.
} 
tradizei mais claramente com a verdade (...)”23. Assim, inversamente, Agostinho assiste à ascensão do Verus Israel ${ }^{24}$ — o verdadeiro Israel — já prenunciado por Paulo, o Israel espiritual, consubstanciado em sua Igreja e universalizado por sua mensagem: “(...) A esses, portanto, que ou então a partir daqueles acreditaram em Cristo, ou até o momento creem, ou ainda depois, no fim do século hão de acreditar, essas coisas não pertencem ao verdadeiro Israel portanto que verá o Senhor face a face"25.

A expressão Verus ou Verum Israel ${ }^{26}$, lapidada pelo pensamento cristológico, definiu, antes de tudo, um processo politicamente necessário de alegorização exegética dos alicerces da cultura bíblica e sua imediata transferência ao ideário teológico cristão. “(...) A Igreja persegue por amor, os ímpios, por crueldade. (...) Enquanto um persegue amando, o outro o faz odiando" ${ }^{27}$. Em sua Epístola CXXXV, vendo o conjunto dos homens como um único ser, sintético e indivisível, análogo ao lógos platônico, Agostinho propóe a necessidade de coibir e desarticular as forças consideradas inautênticas. Aponta aqueles que, em sociedade, representam a prova viva do não acatamento ao Verbum e da ausência de Deus: judeus e heréticos.

Ao discutir as razões do "desvio" donatista, o bispo de Hipona constrói uma de suas principais hipóteses sobre o "erro". Pelos alicerces discursivos paulinos, finda por situar heréticos e judeus em um mesmo campo sêmantico. Por ignorarem a graça divina e fazerem mau uso da razão em suas escolhas religiosas, o bispo declara que: “(...) Quando o apóstolo afirma dos judeus que estes ignoram a justiça de Deus, porém não segundo a razão, os torna semelhantes a vocês"28.

Conscientemente retirados de sua própria historicidade, deslegitimados e "comprovadamente" maus, judeus e hereges justificam, por seus falsos existires, os trágicos destinos que lhes são impostos, além do dever eclesiástico da fé combativa. Em Confessiones, Agostinho revela exatamente a essência e o significado da maldade, elemento do náo ser que jamais poderia estar vinculado a Deus, mas a um perverso exercício de desvio da verdade ${ }^{29}$.

Neste universo de representaçôes sociais, a Igreja, ancorada pelo poder das leis imperiais, torna-se o único locus atuante de justiça, devendo zelar pela liberdade de toda a humanidade, sob respaldo da fé e da lei. $\mathrm{O}$ apelo do discurso agostiniano pela unidade religiosa adquire expressividade quando se alia aos poderes herdados do Estado, aqui consubstanciado na aplicação e no temor pelas leis de um Império em crise:

(...) A mim foi revelado, em primeiro momento, que minha própria cidade natal, que pertencia inteira ao partido de Donato, converteu-se à unidade católica pelo temor às leis imperiais. (...) Por tudo isso, o terror que provocam essas leis, por cuja promulgação os reis servem à Deus no temor da fé, foi tão proveitoso, que muito agora afirmam: "Bem que o desejávamos"30.

$\mathrm{Na}$ concepção de um devir histórico humano que somente ocorreria via ecclesia, o destino judaico encontrar-se-ia teleologicamente determinado. Assim como procederia com heréticos, a Patrística agos-

${ }^{23}$ AUGUSTINI HIPPONENSIS. Tractatus Adversus Iudaeos. In: PATROLOGIA LATINA database, op. cit. v. 42, Caput VII, 10.

${ }^{24}$ Para esta questão ver a obra de SIMON, Marcel. Verus Israel: étude sur les relations entre chrétiens et juifs dans L’Empire Romain. Paris: Boccard, 1964.

${ }^{25}$ AUGUSTINI HIPPONENSIS. Tractatus Adversus Iudaeos, op. cit. v. 42, Caput V, 6.

${ }^{26}$ La polémique anti-juive. Caractères et méthodes. SIMON, Marcel. Verus Israel, op. cit. p. 165.

${ }^{27}$ AUGUSTINI HIPPONENSIS. De correctione donasticorum liber. Epistola CLXXXV. In: PATROLOGIA LATINA database, op. cit. v. 33, Caput Primum, 11.

${ }^{28}$ AGOSTINHO DE HIPONA. Cartas. In: OBRAS de San Agustín, op. cit. Carta 93, "A Vicente Rogatista (año 408)”, Caput II, 10.

${ }^{29}$ AUGUSTINI HIPPONENSIS. Confessiones, op. cit. v. 42, Liber VII, Caput 16.

${ }^{30}$ AGOSTINHO DE HIPONA. Cartas, op. cit. Carta 93, “A Vicente Rogatista (año 408)", Caput V, 17. 
tiniana transforma a trajetória existencial do povo judeu em uma sucessão de ilusôes, falsas escolhas e equívocos religiosos.

Um dos baluartes históricos que, segundo Agostinho, comprovou o declínio judaico e sua necessária substituição por um "novo Israel” foi a perda de Jerusalém, seu desmantelamento físico e religioso, puniçóes divinas implacáveis. Neste processo de transformação institucional e sacerdotal ocorridos na Judeia a partir de 70 d.C., a expulsão definitiva dos judeus de Jerusalém sinalizaria apenas o prenúncio da condição errante de vida à qual estariam condenados. Por vida errante entender-se-ia a marca soteriológica de infortúnios, sucessivos desterros e, em última instância, pelo sofrimento moral. Algozes e simultaneamente testemunhos da morte de Deus, os judeus deveriam sobreviver, a princípio, para comprovar os desígnios cristãos sobre a história. Roma insere-se nesse contexto como uma entre várias potências que poderiam ser salvas pela aceitação cabal da fé cristá.

Neste sentido, universalismo e providencialismo tornam-se pressupostos indissociáveis, uma vez que Roma - e sua história - assume o caráter de providenciais instrumentos divinos. Através dela (Roma), Deus externa toda sua ira sobre o povo que o rejeitara. A destruição do templo de Jerusalém não teria, enfim, qualquer teor acidental para o autor hiponense. Foi profetizada em função dos "crimes" cometidos pelos judeus.

Logo, em substituição à antiga ordem institucional judaica destruída por Deus, eis que um novo templo seria erguido. A Igreja, "a boa semente", que cresceria em todas as partes entre as cinzas, fora conservada por Deus para que, finalmente, pudesse "se apoderar de todas as naçóes, inclusive as bárbaras". Nesta fala, Agostinho justifica a necessidade de difusão institucional da Igreja, aliada aos projetos de evangelização, não como atos idiossincráticos de alcance "de nossa própria justiça”. Antes, como o cumprimento de uma profecia, entende que a germinação da semente eclesiástica estava prevista nas Escrituras, portanto, há muito prometida pelo Verbum ${ }^{31}$.

O mito agostiniano de salvação eclesiástica fundamentado nos escritos paulinos opóe de forma circunstancial os intentos cristãos, "verdadeiros", ao caráter conspiratório judaico. Esta suposta inclinação às "tramas secretas', atribuída aos judeus já desde inícios dos século IV, endossa as certezas agostinianas com relação ao "destino" a ser imposto por Deus a este "povo". Quando aborda o destino diaspórico dos judeus, Agostinho percorre os mesmos recursos semânticos recorridos por Eusébio de Cesareia, quase um século antes. ${ }^{32}$ Os intelectuais da Patrística, ancorados nos saberes helenísticos, erigiram uma inédita hermenêutica sobre a Bíblia hebraica, utilizando-a como argumento de autoridade suficiente para delegar, aos judeus, uma existência efêmera e transitória. Além disso, os textos hebraicos adquirem função profética de anunciar a perene existência de Jesus ${ }^{33}$ e, consequentemente, os equívocos e pecados da fé judaica. A diáspora judaica seria, assim, obra da justiça divina contra os males causados pelos judeus. Logo, o deicídio encontra-se no âmago de seus influxos punitivos:

(...) E, se não pecassem contra Ele com ímpia curiosidade, cedendo à sedução das artes mágicas, e não adorassem deuses estranhos e ídolos e, ultimamente, não matassem Cristo, permaneceriam no mesmo reino, se não mais espaçoso, pelo menos mais feliz. $\mathrm{O}$ fato de estarem agora dispersos por quase todo o orbe e entre todas as gentes é providência do único Deus verdadeiro, a fim de seus livros serem documento certificador de que isso já estava profetizado havia muito $(. . .)^{34}$.

\footnotetext{
${ }^{31}$ AGOSTINHO DE HIPONA. Cartas, op. cit. Carta 93, “A Vicente Rogatista (año 408)”, Caput IX, 28 ; Caput IX, 31. ${ }^{32}$ EUSEBIO PANFILIO, O Bispo de Cesaréia. Historia eclesiastica. Edición bilingüe. Traducción, introducción y notas de Argemiro Velasco Delgado. Madri: BAC, 2001; EUSEBIUS. Ecclesiastical history. Cambridge: Harvard University Press, 1992. (Loeb Classical Library).

${ }^{33}$ AUGUSTINI HIPPONENSIS. Confessiones, op. cit. Liber XIII, Caput V.

${ }^{34}$ AGOSTINHO DE HIPONA. A cidade de Deus contra os pagãos, op. cit. Liber IV, Caput XXXIV.
} 
Como vemos, a questão judaica, uma vez comparada à herética, exigiu de nosso autor que transcendesse à tese do "povo testemunho do sacrifício de Deus". Agostinho reflete agora náo apenas sobre a presença judaica como comprovação da existência de Cristo, ou sobre os judeus como agentes de sua morte. Unindo ontologia platônica à teologia cristá, considera, sobretudo, a inautenticidade desse existir judaico, sua incoerência, seu erro.

$\mathrm{Na}$ citada carta dirigida ao bispo Vincentio (Vicente Rogatista), Agostinho tece duras críticas à heresia donatista, e defende, inédita e antagonicamente a todos os seus escritos, a necessidade de transformação (conversão), sob temor e força, de todos os inimigos da unidade. Atitudes que, segundo ele, em nada afastariam perseguidores e perseguidos da tão almejada salvaçáo. Por isso argumenta com Vincentio, tentando dissuadi-lo de sua discordância, explicando o porquê de sua "nova arbitrariedade". Em suas contra-argumentaçôes epistolares, Agostinho reconhece a não unanimidade de seus métodos, muito embora defenda seus usos:

(...) Não afirmo que se possa ser bom à força, mas sim que se teme padecer. O que não quer [padecer] abandona o obstáculo de sua animosidade ou se sente impelido a conhecer a verdade até então ignorada. (...) Pela circunstância deste temor que a você desagrada, [heréticos] se fizeram católicos graças às leis dos imperadores. $(. . .)^{35}$.

$\mathrm{Na}$ transição do pensamento estigmatizante para as práticas efetivas de perseguição, a obra agostiniana demonstra exatamente fortes desníveis entre produção de discurso e aplicação discursiva ${ }^{36}$. Em diversos momentos, a experiência (religiosa, social e política) torna-se de fato irredutível ao discurso, e constrói, através de sucessivos exercícios de reinterpretação simbólica, novas práticas e dinâmicas sociais de representação e atuação. A esta transitividade de pensamento do bispo hiponense, que não necessariamente obedece a critérios cronológicos, denominamos de "giro agostiniano".

Em nossa análise, a condição histórica da retórica agostiniana acumula, ao longo de sua própria narrativa, diversas tensôes e manipulaçôes inerentes à construção do discurso. Sua própria experiência social, seus conflitos teológicos e embates culturais o levaram a transformar e reinterpretar valores por ele mesmo erguidos em momentos mais contemplativos da vida. Seus dilemas mais críticos aparecem de forma lapidar em diversos trechos de sua epístola a Vicente Rogatista, já citada anteriormente. No capítulo IX, Agostinho externa toda sua preocupação com a necessidade de superação numérica da população cristã sobre a de pagãos e judeus. Torna seu projeto universalista uma questão de alteridade e orgulho religioso, pois temia atitudes de escárnio e rechaço de judeus e pagáos, motivadas por uma inferioridade que deveria ser solucionada:

(...) Temeis que, se sois obrigados a entrar na cidade através das leis imperiais, o nome de Deus será blasfemado cada vez mais por judeus e pagãos. (...) Certamente, se judeus e pagãos acreditassem que os cristãos sejam tão poucos como vocês, que são exclusivamente conhecidos como cristãos, dignar-se-iam a blasfemar contra nós. Não cessariam de $\operatorname{rir}^{37}$.

Ao refletirmos, portanto, sobre os processos de continuidade e persistência dos mitos, identificamos vetores de construção de identidades de sinais contrários, “(...) é que nos períodos críticos que os mitos políticos afirmam-se com mais nitidez, impóem-se com mais intensidade, exercem com mais violência

\footnotetext{
${ }^{35}$ AGOSTINHO DE HIPONA. Cartas, op. cit. Carta 93, “A Vicente Rogatista (año 408)”, Caput V, 16 ; Caput V, 17.

${ }^{36}$ CHARTIER, Roger. Por uma sociologia histórica das práticas culturais. In: História cultural: entre práticas e representaçôes. Lisboa: Difel, 1992. p. 13-28.

${ }^{37}$ AGOSTINHO DE HIPONA. Cartas, op. cit. Carta 93, “A Vicente Rogatista (año 408)”, Caput IX, 26.
} 
seu poder de atração" 38 . Nesse viés, todo pensamento mitológico-político fundar-se-ia a partir de fenômenos de crise, abalo, ou mesmo rupturas drásticas da ordem social. O impacto simbólico causado pelo saque de Roma pelos godos de Alarico em 410 e o temor crucial quanto ao destino da Ecclesia indicam, no discurso de nosso autor, a formação de comportamentos ambíguos em relação aos cristãos e, principalmente, aos judeus.

O mito unitário, salvacionista e antijudaico de Agostinho veio a ser construído exatamente quando o autor vivenciava uma crise moral de caráter religioso. Testemunhava, ainda, a fragilidade das estruturas políticas sinodais da ecclesia katoliké, erigidas ainda em tempos romanos pois, “(...) é no mito, escreve Roger Caillois, que se apreende melhor, ao vivo, o conluio das perturbaçóes mais secretas, mais virulentas do psiquismo individual e das pressóes mais imperativas e mais perturbadoras da existência social" 39 .

Reconhecendo os fossos existentes entre discursividade e experiência, verificamos que nosso autor, um tanto aflito pelas manifestaçóes destoantes aos propósitos católicos de unidade e equilíbrio (crise romana, heresias e judaísmo), não se ateve à ideia da sobrevivência judaica e de seu testemunho em sociedade. Antes pelo contrário, chega a propor transformaçôes irreversíveis nessa condição judaica.

O sofrimento, resultante de um ato persecutório, adquire louvável conotação universal. $\mathrm{O}$ amor pela humanidade fez com que a Igreja recebesse encargos divinos que, embora a alguns pudessem parecer opressivos, na verdade, traziam mensagens maternais e salutares. Nas cartas, encontramos o uso legítimo e acentuado da violência física e simbólica, ambas componentes práticos de um projeto divino universalista que "(...) necessariamente tem que provocar-lhes mal a uns e outros, pois a todos ama" 40 . Para Agostinho, externando os malefícios oriundos da resistência à fé cristá, os fins justificariam os meios.

Em interessante comentário a Festo, em 406, o bispo de Hipona utiliza-se ainda de diversas metáforas que se referem à infidelidade enquanto enfermidade. Agostinho aludia a um mal que deveria ser extirpado por aquilo que ora define como amor. Ainda que muitas vezes incompreendido, o amor manifestado pela Igreja apareceria na forma de castigos e moléstias, que deveriam ser aplicadas nos processos de "cura dos enfermos":

Porém a diligência da caridade persiste, castigando os delirantes, agitando os letárgicos, a ambos amando. Ambos são molestados, porém também amados; ambos são molestados, porém ambos sentem a gratidão quando sanados, ainda que tenham se indignado quando ainda enfermos ${ }^{41}$.

O temor às leis imperiais em benefício da verdade e das instituiçôes eclesiásticas, axioma preconizado por Agostinho, relaciona-se à politizaçáo gradativa de um proselitismo cristáo militante, tomado desde Paulo como "mandato universal". Estamos aqui nos referindo ao processo de exclusão objetiva e articulada, aliado a políticas de conversáo obrigatória, sejam essas dirigidas aos hereges ou aos judeus. Como podemos perceber, ainda que secundariamente tomadas pela historiografia como referências documentais sobre a polêmica antijudaica, as epístolas de fato apresentam, em nosso entendimento, dados reveladores do pensamento agostiniano.

$\mathrm{Na}$ já citada epístola a Vicente Rogatista, nosso autor estabelece analogamente a relação entre a violência sofrida por Paulo ao longo de sua vida e os benefícios deste ato para o apóstolo, cujo escopo seria o de "reter e conhecer a verdade". Se Paulo fora subjugado pela violência sofrida e gerada por Cristo, por que não seria legítimo à Igreja violentar seus inimigos por amor e piedade dos mesmos? ${ }^{32}$

\footnotetext{
${ }^{38}$ GIRARDET, Raoul. Mitos e mitologias politicas. São Paulo: Companhia das Letras, 1987. p. 180.

${ }^{39}$ Ibidem, p. 201.

${ }^{40}$ AGOSTINHO DE HIPONA. Cartas, op. cit. Carta 89. “A Festo”, Parágrafo 6.

${ }^{41}$ Ibidem.

${ }^{42}$ Idem, Cartas, op. cit. Carta 93, “A Vicente Rogatista (año 408)”, Caput II, 5.
} 
Certamente, o "giro agostiniano" legou à Idade Média ocidental argumentos de autoridade indispensáveis para a reprodução de práticas sociais de representação outrora apresentadas em caráter discursivo, tais como a coerção religiosa e a conversão. $O$ giro agostiniano demonstra ao historiador as possibilidades múltiplas de manipulação e transformação dos mitos. $\mathrm{O}$ polimorfismo que caracteriza o pensamento mitológico da Patrística adversus iudaeos ${ }^{43}$ permite ir além das evidências constatadas nos discursos episcopais mostrando que os projetos de dominação camuflam, na realidade, transiçóes discursivas, tornando seu estudo mais complexo e, simultaneamente, mais indiciário.

${ }^{43}$ Cf. GIRARDET, Raoul. Mitos e mitologias politicas, op. cit. p. 17. 